- anizations which have been monitoring organization over the last five years (see the ICVA resolution on page 6).

agencies working in the refugee The agme under the co-ordination of the program have recently been informed by the UNHCR that the Honduran government is UNHCR interested in the "Mexican Model". very Mexico, the government is directly (In Mrible for the administration of the responsio programme through COMAR, the refugee pront refugee commission.) Over the governmear and a half, the Honduran last year has frequently complained in governmenturan press that it has no control the He camps. In November 1984, it over the issue of a permanent Honduran government presence in the camps. When questioned with regard to what type of questie CONARE would place in the camps, Colonel Turcios replied that they were considering using retired military considennel. To date, no concrete action has resulted from this, but now that has ation is no longer on the agenda, it relocars that the Honduran government's interest in this proposal has been revived.

There are also other indications that the Honduran government is making a move to assert control over the situation. Three of the most recent indications are:

1. In mid-February, two articles in the Honduran press announced that MSF Médecins Sans Frontières, the French medical agency whose international volunteers run the health programme in the camps) would be asked to leave the programme by May of this year and would be replaced by Honduran doctors. The incident that provoked the story, concerning a Honduran doctor who blamed MSF for losing his job, was blown out of proportion by the Ministry of Health which used the occasion to lobby against the presence of MSF in the refugee programme. Lengthy negotiations were necessary to ensure the continued participation of international medical personnel in the programme. (The presence of international agency personnel in the camps has always been extremely important in terms of the security of the refugees.)

2. On February 19, the immigration officials in San Marcos, near the camp of Mesa Grande, informed the UNHCR that no new male refugees between the ages of 18 and 50 would be allowed to enter the camps. Several men in this age bracket had just arrived and Honduran immigration officials were threatening to deport them. These new refugees were kept in the UNHCR house in San Marcos until the UNHCR was able to negotiate their entrance into Mesa Grande. In the end the UNHCR also was able to have the new restriction rescinded. The successful resolution of this particular crisis through the immediate intervention of the UNHCR only serves to underline the importance of its presence in the camps at all times.

3. It appears that all requests for permission to enter the camps, both for visitors as well as for new staff persons, must now be addressed directly to Colonel Turcios. Previously, requests were made to Colonel Turcios via the UNHCR.

Of primary concern in this increasingly complex situation is how to guarantee security when the very authorities that have been responsible for threats to the security of the refugees are beginning to insist on more control over the camps. Although the Honduran government has a sovereign right to determine what happens within its territory, this does not relieve it of its international legal obligations to respect the human rights of the refugees within its borders. Since there are no international mechanisms which guarantee that these legal obligations are respected, the international community has a moral obligation to defend a refugee population whose human rights are being threatened.

Experience over the last few years has shown that international pressure with regard to this issue has been extremely effective. Although it appears that all plans to relocate Salvadorean refugees from Colomoncagua and San Antonio have been officially cancelled, the position of the refugees continues to be extremely precarious. In the context of escalating intimidation and harassment of the refugees by the Honduran military, the continued role of the UNHCR in the co-ordination of the programme, and the presence of sufficient numbers of qualified UNHCR protection officers and international agency staff in the camps continue to be essential for the security of the Salvadorean refugees.

Sandra Pentland is an associate of the Jesuit Centre for Social Justice. Denis Racicot is an immigration lawyer. Both work with the Comité de travail sur les réfugiés (COTRAC) in Montreal.

\section{From \\ Howard Adelman: Next Year on Sabbatical}

I wish to thank all those graduate students at York University who have helped produce this year's Refuge. Alex Zisman and Tanya Basok, in fact, assumed full editorial responsibility for this excellent current issue on Central American refugees. Without the help of Leslie Rider, my research assistant and the Managing Editor, we would all be lost.

I also wish to thank our loyal readers whose continuing subscriptions and extra support have enabled us to continue to publish Refuge. I hope we have made a contribution to the understanding of the problem of refugees and the policy issues with which we all must grapple.

Next year I am away on sabbatical. In 1979 , at the beginning of my last sabbatical, I got caught up in the refugee issues of the Boat People and Operation Lifeline. Since then I have sustained that involvement and helped develop the refugee research unit at York University and the publication Refuge. It is time to resume my concentration on my work in philosophy while I write the results of my research on refugees.

Michacl Lanphier, Professor of Sociology at York University, succeeds me as Director of the Refugee Documentation Project and Editor of Refuge. Michael has a distinguished record as both a scholar dealing with refugee issues and as a committed individual. Alex Zisman will assist Michael by serving as Feature Editor of Refuge and Noreen Nimmons will take over as Managing Editor.

I am sure you all join me in wishing them and all the others associated with the Refugee Documentation Project at York University the best in their future work.

Howard Adelman 